\title{
ЭКОНОМИЧЕСКОЕ СОТРУДНИЧЕСТВО СТРАН БРИКС В УСЛОВИЯХ ПАНДЕМИИ
}

\author{
(c) 2020 Гусарова Светлана Анатольевна \\ доктор экономических наук, доцент, ведущий научный сотрудник \\ Российский экономический университет имени Г.В.Плеханова, Россия, Москва \\ E-mail: s-gusarova@mail.ru
}

В работе исследованы основные направления сотрудничества стран БРИКС (Бразилии, России, Индии, Китая, ЮАР) в условиях пандемии коронавируса, раскрывается помощь, которую они оказывают друг другу в сложных условиях. Определены шоки, с которыми сталкиваются экономики стран в условиях коронавируса. Выявлены риски, связанные с проблемами, стоящими перед многими государствами при выходе их из кризиса.

Ключевые слова: страны БРИКС, экономическое сотрудничество, риски выхода из кризиса.

\section{1. Введение}

Все страны мира с начала 2020 года, оказались в очень сложных условиях борьбы с пандемией коронавируса. Многие государства были вынуждены ввести режим самоизоляции, приостановив работу некоторых производств.

По прогнозам Международного валютного фонда (МВФ) спад мировой экономики в 2020 году составит 3\%. В 2020 году предполагается рост ВВП Китая на 1,2\%, экономика Индии увеличится на 1,9\%. Объем ВВП остальных стран БРИКС в 2020 году будет значительно снижен в России на 5,5\%, Бразилии - на 5,3\%, ЮАР - на $5,8 \%[10]$.

Страны БРИКС помогают друг другу справиться с проблемами пандемии, оказывают друг другу экономическую, экспертную и гуманитарную помощь. С этой целью государства «Пятерки» расширяют свое внутригрупповое сотрудничество как в экономической, так и в политической сферах в условиях смены геополитической парадигмы развития и формирования новых систем лидерства на мировой арене.

\section{2. Состояние экономики стран БРИКС}

Четыре из пяти стран БРИКС в 2018 году входили в ТОП-20 крупнейших экономик мира. Китай по номинальному ВВП занимал второе место в мире (13608 млрд. долл.), Индия была на пятом месте (2779 млрд. долл.), Россия - на одиннадцатом (1661 млрд. долл.), Бразилия - на восьмом (1869 млрд. долл.), ЮАР - на 32 месте в мире (308,1 млрд. долл.) [8].

Пандемия коронавируса 2020 года отразиться на экономиках всех стран мира, в том числе государств БРИКС. По мнению экспертов международного рейтингового агентства (Fitch), ни одна страна мира не сможет избежать разрушительных последствий пандемии коронавируса [9]. По расчетам Азиатского банка развития, объем мировой экономики из-за пандемии коронавируса уменьшится в 2020 году на 5,8-8,8 трлн. долл. [1].

Объем ВВП Китая за первый квартал 2020 года в результате коронавируса снизился на $6,8 \%$. Отрицательная динамика развития экономики Китая была зафиксирована впервые с 1992 года. На уменьшение темпов роста ВВП Китая повлияло не только приостановка деятельности многих предприятий в результате пандемии, но «торговая война» между КНР и США. В мае 2020 года США вновь решили ужесточить санкции против Китая, подозревая его в сокрытии информации о коронавирусе и требуя предоставления полной информации о причинах пандемии.

Во всех странах БРИКС наблюдается падение внутреннего и внешнего спроса на товары и услуги, снижение активности в сфере услуг и обрабатывающей промышленности, значительное снижение доходов компаний во многих отраслях экономики, уменьшение объемов торговли.

По прогнозу Центрального банка РФ, снижение объема ВВП России составит к концу 2020 года 4-6\%. Ожидается снижение объема экспорта России в 2020 году на 10-15\%, объема инвестиций - на 6-10\% [3].

Как и в других странах мира (в том числе БРИКС), правительство Индии ввело на территории страны меры изоляции для борьбы с влиянием коронавируса. Развитие пандемии приве- 
ло к серьезным сбоям в цепочках добавленной стоимости, отмене ранее заключенных договоров. Результаты пандемии в первую очередь оказали влияние на замедление темпов развитие сельского хозяйства, торговли, транспортной и гостиничной сферы Индии. В результате объем импорта товаров снизился по сравнению с данными в апреле 2019 года в 1,6 раза с 41,4 млрд. долл. до 17,1 млрд. долл. Из-за снижения деловой активности, объем импорта нефти в апреле 2020 года уменьшился в 1,6 раза до 4,7 млрд. долл.[7].

Международное рейтинговое агентство (Fitch) прогнозирует снижение объема ВВП Бразилии на 4. На этот процесс оказывает влияние не только пандемия коронавируса, но и глобальная рецессия, замедление темпов роста экономики Китая (основного торгового партнера Бразилии), сокращение потока иностранных инвестиций, снижение цен на сырьевые ресурсы, уменьшение внутренней активности, высокий уровень безработицы. Правительство Бразилии, в отличие от других стран БРИКС и многих стран мира, не отнеслось к пандемии коронавируса серьезно. Поэтому в стране не были предприняты экстренные меры по изоляции населения. В результате крупнейшая экономика Южной Америки, столкнувшись с очень тревожной ситуацией, заняв шестое место в мире по количеству подтвержденных заражений коронавирусом.

Для борьбы с коронавирусом в ЮАР на пять недель был введен карантин (до 1 мая 2020 года). Затем последовало некоторое послабление из-за возможных проблем в социальной и экономической сферах. Национальное казначейство страны прогнозирует сокращение экономики ЮАР на 5,8\% в 2020 году и ее рост на 4\% в 2021 году [2].

\section{3. Сотрудничество стран БРИКС в совре-} менных условиях

В 2020 году Россия является председательствующей страной в группе БРИКС. Государства «Пятерки» работают над созданием «Стратегии экономического партнерства стран БРИКС до 2025 года». В новую Стратегию будут включены вопросы, связанные с совместными подходами в борьбе с эпидемией и преодолением экономических последствий кризисов, а также с поддержкой многосторонней торговой системы, раскрытием потенциала цифровой экономики, устойчивым и инклюзивным развитием в условиях пандемии коронавируса.
Помощь государствам «пятерки» в преодолении кризисных последствий и в борьбе с коронавирусом оказывает Новый банк развития БРИКС (НБР). Было одобрено предоставление кредитной линии Китаю в размере 7 млрд. юаней (около 1 млрд. долл.) и Индии на 1 млрд. долл. Рассматривается возможность выделения Бразилии и ЮАР по 1 млрд. долл. в качестве экстренной помощи для борьбы с коронавирусом. НБР обладает финансовыми возможностями оказания антикризисной помощи странам БРИКС для восстановления экономик после пандемии коронавируса в размере 15 млрд. долл. НБР сможет финансировать поддержку здравоохранения до марта 2021 года. Будет создан Фонд экстренной помощи для стран - членов НБР

В России принято решение осуществить вложение средств Фонда национального благосостояния в юани (а не только в доллары США, евро, фунты стерлингов, японские иены, австралийские доллары, канадские доллары и швейцарские франки) и в китайские государственные облигации.

Председатель КНР Си Цзиньпин отметил, что «стратегическое сотрудничество России и Китая, пройдя испытание эпидемией, станет еще прочнее, а дружба народов двух стран непременно и дальше будет крепнуть день ото дня» [5]. Китай и Россия намерены укреплять противоэпидемиологическое сотрудничество, обмениваться опытом по профилактике и лечению коронавируса, совместно с другими странами БРИКС реагировать на общие угрозы и вызовы в сфере здравоохранения.

Китай, оказывая помощь России в борьбе с коронавирусом, передел на безвозмездной основе 7 млн. таблеток гидроксихлорохина. Также в Россию будет доставлено 20 млн. масок и 1,6 млн. защитных костюмов из Китая.

Россия, в свою очередь, тоже оказывала помощь Китаю в борьбе с коронавирусом. В Китай из России было отправлено 23 тонны медицинских масок, защитных очков, перчаток и одежды. При необходимости, Россия и Китай готовы будут оказать такую помощь другим странам, в том числе государствам «пятерки».

За январь-апрель 2020 года товарооборот между Россией и Китаем увеличился до 33,6 млрд. долл. Экспорт российских товаров в Китай увеличился за этот период в 1,1 раза до 20,4 млрд. долл., китайский экспорт в Россию несколько снизился до 13,1 млрд. долл. [6]. Несмо- 
тря на падение внутреннего спроса на топливо в результате пандемии, в марте 2020 года объем экспорта нефти из России в Китай вырос в 1,3 раза - до 7,02 млн. тонн, или 1,66 млн. баррелей в сутки [4].

Одним из важнейших нефтегазовых проектов для России и Китая является «Сила Сибири» - тридцатилетний контракт на поставку российского газа в Китай на сумму 400 млрд. долл. Протяженность газопровода по территории России равняется 3 тысячам км, а по территории Китая - 5,1 тысячам км. Первая часть газопровода в Китае (восточный магистральный газопровод Россия-Китай) между Хэйхэ и Чанлин уже построена. Еще одна его часть ЧанлинЧунцин будет введена в действие в 2020 году. Это позволит получить Китаю уже в 2020 году 5 млрд. кубометров газа из России. Оставшаяся китайская часть газопровода Чунцин-Шанхай будет построена в 2023 году, что позволит увеличить поставки российского газа в Китай до 38 млрд. кубометров в год.

Важное значение для расширения торговли между двумя странами имеет создание автомобильного моста через реку Амур между Благовещенском (Россия) и Хэйхэ (КНР). Длина моста составляет более одного километра, а протяженность перехода - 20 км (13 км на территории России и 6 км на территории КНР). Инвестиции в строительство моста составили 18,8 млрд. рублей. Грузопоток по мосту составляет 6 млн. тонн (300 тысяч автомобилей) в день, пассажиропоток - 3 млн. человек в день.

Россия и Индия являются давними партнерами в сфере военно-технического сотрудничества. Совместной российско-индийской разработкой является сверхзвуковой ракетный комплекс «БраМос» (BrahMos). В 2020 году Россия и Индия договорились об увеличении радиуса действия сверхзвуковой крылатой ракеты до 600 кM.

Индия объявила тендер на закупку 110 истребителей. Россия представила на этот тендер новый истребитель МИГ-35. Если России удастся выиграть тендер, то лизинговое производство МИГ-35 будет организовано в Индии.

Достигнута договоренность на поставку Россией в Индию дополнительно шести вертолетов Ка-31, выполняющих функцию радиолокационного дозора. Также планируется поставка и ор- ганизация лицензионного производства в Индии ПЗРК «Игла-С» и дополнительная поставка Миг 29UPG.

На вооружение Индии будет поставлен российский автомат АК-203, который с 2020 года в течение десяти лет будет производиться в Индии. Мощность завода в Индии составляет 75 тысяч автоматов АК-203 в год.

Индия является крупнейшим в мире производителем гидроксихлорохина. В Россию было поставлено 100 млн. таблеток этого лекарства.

В условиях пандемии Индия и Китай отметили 70-летие установления дипломатических отношений. Несмотря на то, что их отношения носят характер соперничества-сотрудничества, они объявили о начале «новой эры» в своем взаимодействии.

Россия в мае 2020 года отправила в ЮАР первую партию гуманитарной помощи

\section{4. Выводы}

Современный кризис, связанный с пандемией коронавируса, подтверждает важность укрепления стратегического внутригруппового сотрудничества стран БРИКС, является катализатором расширения их взаимоотношений в различных отраслях экономики. Проведенное исследование позволило выявить риски, с которыми многие страны мира могут столкнуться при выходе из кризиса: продолжение эпидемии коронавируса может оказать влияние на коррекцию сроков отмены карантинных мероприятий в разных странах и привести к неравномерному восстановлению мировой экономики; расширение санкций против многих государств (например, против России, Китая); переполнение запасов нефти в хранилищах многих стран мира; обострение отношений в сфере международной торговли («торговая война» между КНР и США); изменение интенсивности стимулирующей экономической политики правительств разных государств и центральных банков.

Экономика России оказалась под влиянием следующих шоков: сокращение размера нефтяных котировок; санкции, введенные США и ЕС против многих компаний России в различных секторах экономики; сокращение глобальной потребности в нефти, а, следовательно, добычи и экспорта нефти. 


\section{Библиографический список}

1. Азиатский банк развития оценил ущерб мировой экономики от вируса // РБК.- Режим доступа: https:// www.rbc.ru/economics/15/05/2020/5ebe145c9a79475ca82eaac8?utm_source=RBC \&utm_campaign=7908d81f1dEMAIL_CAMPAIGN_2020_05_15_03_02\&utm_medium=email \&utm_term=0_140f2882c5-7908d81f1d-50810719 (дата обращения: 15.05.2020).

2. В ЮАР озвучили прогноз падения экономики в 2020 году // Информационное агентство «Красная звезда».Режим доступа://rossaprimavera.ru/news/e7a862fe (дата обращения: 02.05.2020).

3. ЦБ подготовил первый официальный прогноз падения ВВП России в 2020 году // РБК.- Режим доступа: https://www.rbc.ru/economics/24/04/2020/5ea19aff9a7947282c785981 (дата обращения: 24.04.2020).

4. Импорт нефти в Китай из России в марте вырос на 31\% // Информационный портал БРИКС.- Режим доступа: https://infobrics.org/post/30816/ (дата обращения: 05.05.2020).

5. Си Цзиньпин уверен, что сотрудничество России и Китая станет прочнее // РИА Новости. - Режим доступа: https://ria.ru/20200416/1570147658.html (дата обращения: 16.04.2020).

6. Товарооборот России и Китая в январе-апреле вырос до \$33,56 млрд. // Информационный портал БРИКС.Режим доступа: https://infobrics.org/post/30882/ (дата обращения: 14.05.2020).

7. COVID-19 impact: Exports plunge 60.28 per cent in April // Financial Express.- Режим доступа: https://www. financialexpress.com/economy/covid-19-impact-exports-plunge-60-28-per-cent-in-april/1960440/ (дата обращения: 15.05.2020).

8. Economic Trends // UNCTADSTAT.- Режим доступа: https://unctadstat.unctad.org/wds/ReportFolders/ reportFolders.aspx (дата обращения: 12.05.2020).

9. Fitch резко ухудшил прогноз для российской экономики на 2020 год // Интерфакс. - Режим доступа: https:// www.interfax.ru/business/705548 (дата обращения: 22.04.2020).

10. World Economic Outlook 2020 // International Monetary Fund.- Режим доступа: https://www.imf.org/en/ Publications/WEO/Issues/2020/04/14/weo-april-2020 (дата обращения: 05.05.2020). 